\title{
Black carbon concentrations and mixing state in the Finnish Arctic
}

\author{
T. Raatikainen, D. Brus, A.-P. Hyvärinen, J. Svensson, E. Asmi, and H. Lihavainen
}

Finnish Meteorological Institute, Helsinki, Finland

Correspondence to: T. Raatikainen (tomi.raatikainen@ fmi.fi)

Received: 9 April 2015 - Published in Atmos. Chem. Phys. Discuss.: 11 June 2015

Revised: 24 August 2015 - Accepted: 30 August 2015 - Published: 9 September 2015

\begin{abstract}
Atmospheric aerosol composition was measured using a Single Particle Soot Photometer (SP2) in the Finnish Arctic during winter 2011-2012. The Sammaltunturi measurement site at the Pallas GAW (Global Atmosphere Watch) station receives air masses from different source regions including the Arctic Ocean and continental Europe. The SP2 provides detailed information about mass distributions and mixing state of refractory black carbon $(\mathrm{rBC})$. The measurements showed widely varying $\mathrm{rBC}$ mass concentrations $(0-$ $120 \mathrm{ng} \mathrm{m}^{-3}$ ), which were related to varying contributions of different source regions and aerosol removal processes. The rBC mass was log-normally distributed showing a relatively constant $\mathrm{rBC}$ core mass mean diameter with an average of $194 \mathrm{~nm}$ (75-655 nm sizing range). On average, the number fraction of particles containing $\mathrm{rBC}$ was 0.24 (integrated over $350-450 \mathrm{~nm}$ particle diameter range) and the average particle diameter to $\mathrm{rBC}$ core volume equivalent diameter ratio was 2.0 (averaged over particles with $150-200 \mathrm{~nm}$ rBC core volume equivalent diameters). These average numbers mean that the observed $\mathrm{rBC}$ core mass mean diameter is similar to those of aged particles, but the observed particles seem to have unusually high particle to $\mathrm{rBC}$ core diameter ratios. Comparison of the measured $\mathrm{rBC}$ mass concentration with that of the optically detected equivalent black carbon (eBC) using an Aethalometer and a MAAP showed that $\mathrm{eBC}$ was larger by a factor of five. The difference could not be fully explained without assuming that only a part of the optically detected light absorbing material is refractory and absorbs light at the wavelength used by the SP2. Finally, climate implications of five different black carbon mixing state representations were compared using the Mie approximation and simple direct radiative forcing efficiency calculations. These calculations showed that the observed mixing state means
\end{abstract}

significantly lower warming effect or even a net cooling effect when compared with that of a homogenous aerosol containing the same amounts of black carbon and non-absorbing material.

\section{Introduction}

Atmospheric aerosols scatter incoming solar radiation and therefore have a cooling effect on climate, but certain aerosol species such as black carbon also absorb solar radiation, which means that they can have a warming effect (IPCC, 2013; Bond et al., 2013). Light absorbing aerosols have the largest warming effect over reflective surfaces such as clouds, snow and ice. In addition, deposition of absorbing aerosols on snow and ice decreases surface reflectivity which further enhances snow melt (e.g., Hansen and Nazarenko, 2004; Flanner et al., 2007; Svensson et al., 2015). Most of the submicron aerosol light absorption is caused by the broadly defined black carbon (Petzold et al., 2013), but there are also organic carbon particles that absorb especially at ultraviolet wavelengths (so-called brown carbon) and dust which is the main absorbing aerosol type for super micron particles (Bond et al., 2013). Atmospheric general circulation models are used to quantify climate effects of black carbon (BC) aerosols, but it is known that these models are not accurate in simulating the complex aerosol lifecycles including formation, aging, transportation, cloud interactions, and removal processes (e.g., Kipling et al., 2013; Stohl et al., 2013; Genberg et al., 2013; Dutkiewicz et al., 2014; Q. Wang et al., 2014). This means that the model predicted aerosol concentrations and mixing state are generally not in agreement with the observations. Detailed aerosol composition and mixing 
state measurements are therefore needed to assess model accuracies and to improve model parameterizations (Reddington et al., 2013; Schwarz et al., 2013; Samset et al., 2014; X. Wang et al., 2014).

Aerosol interactions with radiation and water vapor depend on the mixing state of the absorbing material (e.g., Adachi et al., 2010; Cappa et al., 2012). For example, the absorbing material can be distributed so that a large fraction of particles contains small amounts of absorbing material or vice versa. From the optical point of view, an aerosol population is externally mixed when not all particles are absorbing and internally mixed when all particles are absorbing. Individual absorbing particles have a wide range of structures starting from small spherules which form chain-like aggregates and usually end up being densely packed clusters mixed with non-absorbing material (e.g. Bond et al., 2013). Typical radiative transfer models describe these as bare or coated black carbon particles or a homogenous mixture of black carbon and non-absorbing compounds. For the unit mass of an absorbing material, internally mixed coated particles absorb more than externally mixed bare particles due to the increased effective cross-sectional area (e.g., Schwarz et al., 2008b). In addition, aerosol interactions with water vapor, which are important for optical properties of droplets and clouds as well as for wet removal processes, depend on the mixing state (e.g., Zhang et al., 2008; Liu et al., 2013). For example, the capability of the initially hydrophobic black carbon particle to act as a cloud condensation nuclei (CCN) increases when coated or mixed with material that is hygroscopic.

There are several instruments for measuring black carbon mass concentrations, but few instruments are able to give any information about the mixing state. The Single Particle Soot Photometer or briefly SP2 (Stephens et al., 2003; Schwarz et al., 2006; Moteki et al., 2007) is probably the most versatile and widely used instrument for measuring mass distributions and mixing state of refractory black carbon ( $\mathrm{rBC}$ ). Refractory black carbon is the fraction of the absorbing carbonaceous material that has a boiling point close to $4000 \mathrm{~K}$ and emits visible light when heated to that temperature (Petzold et al., 2013; Lack et al., 2014).

Long-term measurements of elemental carbon by optical and thermal-optical methods show that concentrations have been decreasing in the Finnish Arctic during the last 4 decades due to the decreased emissions (Dutkiewicz et al., 2014). On the annual scale, the highest concentrations are seen during winter and early spring (Hyvärinen et al., 2011; Dutkiewicz et al., 2014). At that time air masses are typically stable with low boundary layer heights, which allows the accumulation of aerosol pollution. Also, winter is the season when domestic heating by burning wood produces largest black carbon emissions. A modeling study by Stohl et al. (2013) showed that the majority of the observed black carbon is from domestic combustion, but industrial sources and long-range transport also have a significant effect. Al- though there are a few previous airborne SP2 measurements covering the Arctic (e.g., Baumgardner et al., 2004; Samset et al., 2014), they provide a snapshot of rBC mixing state at a specific altitude and location. Long-term surface measurements are also needed as they provide boundary conditions for the vertical distributions and also show how concentrations vary as a function of time (diurnal and annual cycles, aerosol sources and removal processes).

The main purpose of this study is to provide new experimental information about the $\mathrm{rBC}$ mass distributions and mixing state in the Finnish Arctic. The SP2 measurements were conducted at Pallas GAW (Global Atmosphere Watch) station from December 2011 to February 2012. To our knowledge, these are the first published medium-term surface SP2 results from the area and also from the Fennoscandian Arctic. In addition to the mixing state information, trajectory analysis is used to estimate the sources of $\mathrm{rBC}$ and the effects of different sources on $\mathrm{rBC}$ mixing state. We also compare $\mathrm{rBC}$ concentrations with those derived from filterbased optical measurements to see if these are in agreement or depend on the physical properties (e.g. volatility) of black carbon. Finally, climate implications of different black carbon mixing state representations constrained by our observations are assessed based on a Mie approximation and a simple direct radiative forcing efficiency model.

\section{Experimental}

\subsection{Pallas measurement station}

Figure 1 shows the location of the Pallas Global Atmosphere Watch (GAW) station at the northern edge of continental Europe. Measurements were conducted on top of a fell called Sammaltunturi $\left(67^{\circ} 58.400^{\prime} \mathrm{N} 24^{\circ} 6.939^{\prime} \mathrm{E}, 565 \mathrm{~m}\right.$ a.m.s.l. $)$ about $250 \mathrm{~m}$ above surrounding sparsely populated hilly terrain covered by mixed pine, spruce and birch forests (Hatakka et al., 2003). In the absence of significant local aerosol sources, most observed particles are long-range transported from the Kola Peninsula and from more densely populated and industrialized areas from the south. Therefore, Pallas is a site where relatively well-aged air masses can be observed on their way to the north. On the other hand, the site also receives clean air masses from the north.

\subsection{Instrumentation}

The station has instruments for continuous measurements of meteorological parameters, trace gasses and aerosol size distributions and optical properties (Hatakka et al., 2003). During the Pallas winter campaign, a Single Particle Soot Photometer (SP2; Revision $\mathrm{C}^{*}$ with 8 channels) manufactured by Droplet Measurement Technologies (Boulder, CO, USA) was used to measure size distributions and mixing state of refractory black carbon (rBC). We focus on the SP2 mea- 


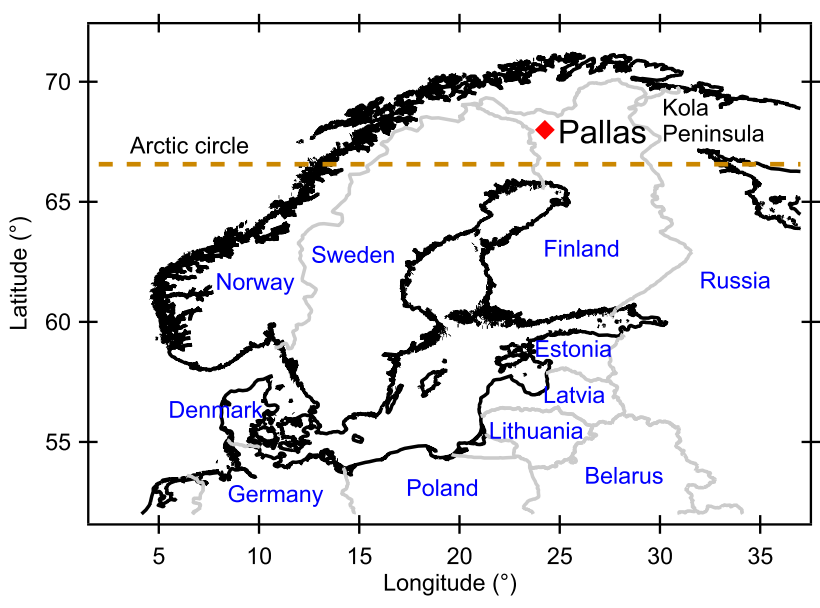

Figure 1. Location of the Pallas GAW station.

surements, but a brief description of the optical black carbon and trace gas measurements is given below.

The measurement station has three sample lines: one is without nominal cut-off diameter (the total line), one has a cyclone for removing particles larger than $10 \mu \mathrm{m}\left(\mathrm{PM}_{10}\right.$ line) and the third one is so-called gas line where inlet design limits the particle size to about $5 \mu \mathrm{m}$. The station is located on top of a fell, which means that it is often covered by low-level clouds. Cloud droplets are formed when water condenses to existing aerosol particles. Since cloud droplets are often larger than $10 \mu \mathrm{m}$, those particles that have formed cloud droplets are missing from the gas and $\mathrm{PM}_{10}$ sample lines. Because the SP2 was connected to the $\mathrm{PM}_{10}$ sample line, results can be biased during these in-cloud events. Similarly, precipitation can decrease aerosol concentrations by washing out particles. Such in-cloud and precipitation events can be identified and possibly filtered using visibility and precipitation data, respectively, from the weather station. Unfortunately, the weather station had only $32 \%$ data coverage for the campaign period. Alternative methods can be used to identify the in-cloud events, which also include most of the precipitation events as precipitation is strongly related to the presence of low level clouds.

Since the weather station data are largely missing, incloud time periods are found by comparing particle number size distributions from two Differential Mobility Particle Sizers (DMPS; see Hatakka et al. (2003) or Komppula et al. (2005) for the description of the measurement setup and instruments). One DMPS was connected to the total line (all particles) and the other was connected to the gas line (no particles from cloud droplets). The difference between the total and gas sample line size distribution gives the dry size distribution of particles from cloud droplets, which are typically larger than $100 \mathrm{~nm}$ in dry diameter (Komppula et al., 2005). In our analysis, the relative difference (i.e. activated fraction) for $260-465 \mathrm{~nm}$ dry size range which is larger than 0.8 is considered as an in-cloud case and a value smaller than 0.2 indicates clear conditions at the station; the remaining points indicate missing DMPS data or unclear or variable cloud conditions. It should be noted that this definition is designed for our purpose since it shows when clouds have a large effect on the observations (more than $80 \%$ of the large particles missing) and when there are no clouds or clouds have a negligible effect on the observations (less than $20 \%$ of the large particles missing).

The station has two continuously operating instruments for absorption measurements (for details see e.g. Hyvärinen et al., 2011; Lihavainen et al., 2015). Thermo Scientific ${ }^{\circledR} 5012$ Multiangle Absorption Photometer (MAAP) and Magee Scientific Corporation AE31 7wavelength Aethalometer collect aerosols to a filter and measure the change in light attenuation. This is then converted to equivalent black carbon (eBC) mass concentration by using instrument-specific parameters (e.g. Petzold and Schönlinner, 2004; Hansen et al., 1984). MAAP data were used as is, but Weingartner correction (Weingartner et al., 2003) was applied to the Aethalometer data. Through discussion of the instrument uncertainties can be found elsewhere (e.g. Lack et al., 2014), but the reported uncertainty for MAAP is about $12 \%$ and it is considered to be more accurate than the Aethalometer. Here we are focused on the MAAP data, because it was connected to the same $\mathrm{PM}_{10}$ sample line as the SP2 while the Aethalometer was connected to the total sample line.

Since some trace gasses are co-emitted with the aerosol black carbon, comparison of $\mathrm{rBC}$ and gas concentrations can give an indication of $\mathrm{rBC}$ sources and the age of the air masses. Concentrations of carbon monoxide and dioxide $\left(\mathrm{CO}\right.$ and $\left.\mathrm{CO}_{2}\right)$, nitrogen dioxide $\left(\mathrm{NO}_{2}\right)$, sulfur dioxide $\left(\mathrm{SO}_{2}\right)$ and ozone $\left(\mathrm{O}_{3}\right)$ were measured using instruments described by Hatakka et al. (2003), except that $\mathrm{CO}$ and $\mathrm{CO}_{2}$ are more recently measured by a Picarro, Inc., CRDS (Cavity RingDown Spectroscopy) analyzer (model G2401).

Detailed description of the SP2 operation principles is given elsewhere (e.g., Stephens et al., 2003; Schwarz et al., 2006; Moteki et al., 2007). Briefly, sample aerosol particles travel through a laser cavity (1064 $\mathrm{nm}$ wavelength), where absorbing refractory particles are quickly heated to a temperature where they emit visible light (laser-induced incandescence). The maximum incandescence signal is proportional to the refractory black carbon (rBC) mass and this dependency is parameterized using size-selected Aquadag ${ }^{\circledR}$ (Acheson Inc., USA) particles, whose masses are calculated using the density parameterization from Gysel et al. (2011). This calibration gives ambient $\mathrm{rBC}$ particle mass $(0.4-260$ fg mass quantification range) and $\mathrm{rBC}$ volume equivalent diameter (75-655 $\mathrm{nm}$ sizing range) is then calculated from the mass by assuming $1800 \mathrm{~kg} \mathrm{~m}^{-3} \mathrm{rBC}$ density and spherical voidfree particles. It should be noted that the real particle structure is typically more complex than just a compact $\mathrm{rBC}$ core coated by a non-refractory material (e.g. Bond et al., 2013). All particles scatter laser light so that the maximum scatter- 
ing signal is proportional to the scattering cross section of the particle, which can be related to particle size and optical constants using the Mie approximation (e.g., Bohren and Huffman, 1983). If a particle contains absorbing material, its maximum scattering signal is decreased due to the evaporation of the non-refractory material. However, the unperturbed maximum scattering signal can be reconstructed using socalled Leading Edge Only (LEO) method (Gao et al., 2007; Metcalf et al., 2012). Again, calibration experiments with size-selected ammonium sulfate particles are used to relate observed (or reconstructed) scattering signals to actual particle sizes. For this calibration we have assumed that ambient particles are spherical and optically similar to ammonium sulfate. The sizing range is $190-535 \mathrm{~nm}$ for non-absorbing particles. Because evaporation of non-refractory material decreases signal-to-noise ratio, the lower sizing limit for absorbing particles is about $300 \mathrm{~nm}$.

SP2 intercomparison experiments by Laborde et al. (2012b) have shown that the measurement uncertainty for calibration experiments using different SP2 instruments range from 5 to $17 \%$ being the smallest for $\mathrm{rBC}$ number and the largest for the size of coated rBC particles. These uncertainties can be considered as a lower limit for the current field measurements. In addition to the typical uncertainties, the results can be biased due to the possible differences between calibration and ambient particle properties such as sensitivity (signal response to a known rBC mass), density, morphology and refractive index (e.g. Moteki and Kondo, 2010; Laborde et al., 2012a, b; Baumgardner et al., 2012; Lack et al., 2014; Taylor et al., 2015). Since these properties are not determined for Arctic aerosol, there is a possibility for a bias that can be larger than the typical measurement uncertainty. More discussion about the potential bias is given in Sect. 3.4.

Hourly average mass and number size distributions and mixing state parameters (number fraction of particles containing $\mathrm{rBC}$ and particle diameter to $\mathrm{rBC}$ core volume equivalent diameter ratios for those particles) are calculated from the single particle data. Concentrations are given at the instrument temperature and pressure. The number fraction of rBC containing particles $\left(N_{\mathrm{rBC}} / N_{\text {total }}\right)$ is calculated from the number size distributions using $350-450 \mathrm{~nm}$ particle size (calculated using the LEO method) range. The $350-450 \mathrm{~nm}$ size range is selected considering LEO sizing limits (reliable results for particles larger than $350 \mathrm{~nm}$ ) and reasonable counting statistics (enough particles in this size range). In practice, this size range is representative of the typical accumulation mode particles. The first results showed that practically all $\mathrm{rBC}$ particles contain non-refractory material. The relative amounts of $\mathrm{rBC}$ and non-refractory material in a particle is described by an average particle diameter (from the LEO method) to $\mathrm{rBC}$ core volume equivalent diameter ratio (briefly particle to $\mathrm{rBC}$ core diameter ratio), $D_{\mathrm{p}} / D_{\mathrm{rBC}}$. The parameter is an average of those of individual $\mathrm{rBC}$ containing particles which $\mathrm{rBC}$ core volume equivalent diameter is $150-200 \mathrm{~nm}$. This $150-200 \mathrm{~nm} \mathrm{rBC}$ core size range has enough particles for good counting statistics and it is in the range where particle sizes can be calculated using the LEO method.

The initial SP2 data analysis showed that some results were dependent on the SP2 chamber temperature, which ranged from 23 to $33{ }^{\circ} \mathrm{C}$ during the campaign. Instrument inter-comparison showed that the SP2 underestimated $\mathrm{rBC}$ compared to the eBC derived from the MAAP, when SP2 temperature decreased below $25^{\circ} \mathrm{C}$, so this SP2 data were ignored. Careful inspection of the SP2 data showed that laser power was most likely decreased below the minimum required for heating $\mathrm{rBC}$ particles to their boiling point. Namely, decreasing temperature and laser power meant that particles reached their boiling points closer to the center of the laser beam. This means that particles that miss the center of the laser beam (particle beam width is about $25 \%$ of the laser beam width; Laborde et al., 2012b) do not always reach their incandescence temperature and therefore are not detected as rBC. When laser power is high enough, incandescence signal is practically independent of the laser power, but scattering signal is always proportional to the laser power. However, comparison of scattering particle size distributions and particle size distributions from DMPS showed that the instrument temperature could have caused about $10 \%$ bias to the scattering size, which is smaller than the typical sizing uncertainty of the instrument. The weak temperature dependency is partly explained by the fact that the scattering detector gain is also temperature dependent, but so that the gain (signal) increases when laser power decreases (SP2 workshop communications, Boulder, CO, USA, 2014). In addition, scattering size calculated from the calibration is roughly proportional to the logarithm of the maximum scattering signal, which is proportional to the laser power, so even a $50 \%$ change in laser power would have a minor effect on the calculated scattering size.

\subsection{Trajectories}

Five-day backward trajectories were calculated using the HYSPLIT model (Draxler and Hess, 1997, 1998; Draxler, 1999). Trajectory end point altitude was set to $500 \mathrm{~m}$ a.g.l. Trajectory calculations were initiated every 3 hours and coordinate points were saved hourly (120 coordinate points in addition to the end point). Parameters describing average altitude above ground level, total length, average direction and average distance were calculated for each trajectory. Average distance and direction are the magnitude and direction of a vector calculated as an average of vectors pointing from Pallas to each of the hourly trajectory coordinate points. The vectors from Pallas to the trajectory coordinate points were initially converted from spherical (latitude and longitude degrees) to Cartesian coordinates (kilometers). Average distance and direction indicate the distance and direction of the source area from the Pallas measurement station, respectively. Trajectories originating from central Europe and 


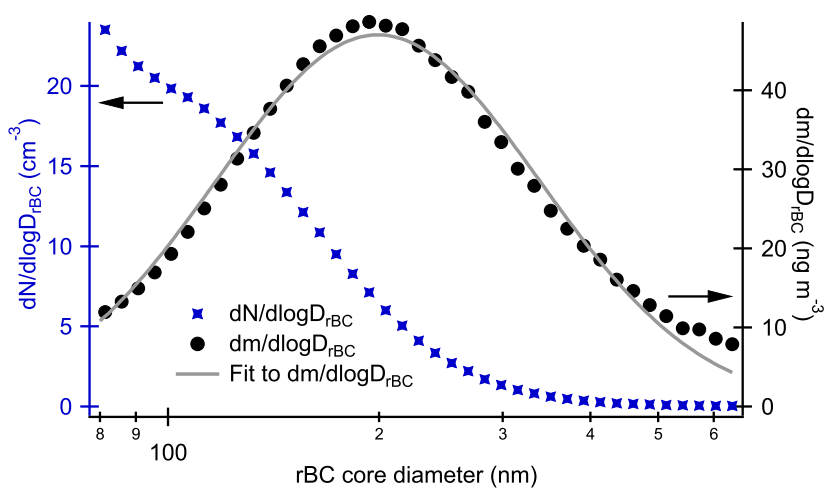

Figure 2. Campaign average rBC mass (black color, right axis) and number (blue color, left axis) size distributions. The solid gray line is a log-normal distribution fitted to the observations (geometric standard deviation is 1.70 , geometric mean diameter is $199 \mathrm{~nm}$ and total area is $27 \mathrm{ng} \mathrm{m}^{-3}$ ).

southern Finland have similar average directions, but these can be distinguished based on the average distance.

\section{Results}

\subsection{Meteorology}

Ambient temperature was initially about $-2{ }^{\circ} \mathrm{C}$ (hourly averages), but decreased throughout the campaign reaching $-24^{\circ} \mathrm{C}$ at the end. Snowfall was observed occasionally, but these and visibility observations were missing from most days (32\% data coverage). The campaign average wind speed was $9 \mathrm{~m} \mathrm{~s}^{-1}$ and the hourly averages were between 1 and $17 \mathrm{~m} \mathrm{~s}^{-1}$. The S-SW was the most frequent wind direction sector and the second was NE-E. The trajectory analysis gave a slightly different view of the origin of the air masses with the dominating sector centered at SE (Eastern Europe) and a minor sector at E (Kola Peninsula). The campaign started on 17 December 2011 during the polar night, which lasts about 3.5 weeks at that location, but at the end of the campaign (2 February 2012) the daily maximum solar radiation reached $30 \mathrm{~W} \mathrm{~m}^{-2}$.

\section{2 $\mathrm{rBC}$ properties}

Figure 2 shows campaign averages of $\mathrm{rBC}$ mass and number size distributions (shown as a function of $\mathrm{rBC}$ core volume equivalent diameter). The peak of the number size distribution seem to be unresolvable due to the $75 \mathrm{~nm}$ detection limit, which means that distribution parameters (total number, mode and width) cannot be calculated or determined from a fit to the data. On the other hand, the observed rBC mass seems to be centered within the sizing range (75$655 \mathrm{~nm}$ ). For example, using the log-normal fit to extrapolate $\mathrm{rBC}$ mass concentration would give $27 \mathrm{ng} \mathrm{m}^{-3}$ when the integrated $\mathrm{rBC}$ mass is $26 \mathrm{ng} \mathrm{m}^{-3}$. Because extrapolation is not needed, log-normal mass distribution parameters (total mass concentration, geometric mass mean diameter and geometric standard deviation) calculated from the observations are used to describe $\mathrm{rBC}$ mass distributions. Because geometric standard deviation is fairly constant, we focus on the total mass concentration and geometric mass mean diameter.

Figure 3 shows the time series of the main $\mathrm{rBC}$ properties including the total mass concentration $\left(c_{\mathrm{rBC}}\right)$ and geometric mass mean diameter $\left(\mathrm{GMD}_{\mathrm{rBC}}\right)$ for the $75-655 \mathrm{~nm}$ $\mathrm{rBC}$ core diameter detection range, number fraction of particles containing $\mathrm{rBC}\left(N_{\mathrm{rBC}} / N_{\text {total }}\right.$; calculated using 350 $450 \mathrm{~nm}$ particle size range), and particle to $\mathrm{rBC}$ core diameter ratio $\left(D_{\mathrm{p}} / D_{\mathrm{rBC}}\right.$; calculated using $150-200 \mathrm{~nm} \mathrm{rBC}$ core size range). Background color indicates when the station is in cloud (blue) and when not (red), and when the presence of clouds is unclear or the DMPS data are missing (white). As explained in Sect. 2.2, SP2 measurements can be biased during the in-cloud time periods, because most activated particles are removed by the inlet system. There are some cases where the changes in the observed aerosol parameters (mainly $\mathrm{rBC}$ mass concentration) can be related to the appearance or disappearance of clouds, but most of the observed variability is caused by other factors such as air mass history. Statistical analysis (not shown) also confirmed that the average aerosol properties were similar during no cloud and in-cloud time periods. Therefore, we use the full data set in the following calculations.

Average rBC mass concentration (the data shown in Fig. 3) is $26 \mathrm{ng} \mathrm{m}^{-3}$, but the values range from about zero to $120 \mathrm{ng} \mathrm{m}^{-3}$ (Fig. 3). Average geometric mass mean diameter is $194 \mathrm{~nm}$ and $90 \%$ of the values are between 161 and $231 \mathrm{~nm}$. The average number fraction of particles containing $\mathrm{rBC}$ is 0.24 and again $90 \%$ of the values are between 0.14 and 0.35 . Finally, the average particle to $\mathrm{rBC}$ core diameter ratio is 2.0 and the $90 \%$ limits are from 1.8 to 2.1. Figure 3 and the $90 \%$ limits show that the $\mathrm{rBC}$ mass concentration varies significantly more than the mixing state parameters and the geometric mass mean diameter.

\subsubsection{Comparison with other SP2 studies}

One complication in comparing SP2 results from different groups and locations is that different calibration materials are being used (e.g. Aquadag ${ }^{\circledR}$ or fullerene soot; Moteki and Kondo, 2010; Laborde et al., 2012a; Baumgardner et al., 2012) and different optical and physical properties (e.g. refractive index, particle structure and density) are assumed for the ambient $\mathrm{rBC}$ and scattering material. There are also different ways to calculate mixing state parameters (e.g. size range). To our knowledge, this is the first published SP2 study where medium-term surface measurements have been conducted at high latitudes during Arctic winter, so direct comparison with other studies is not possible. Nevertheless, published studies can give an idea of how Pallas rBC properties are related to those from different environments. 


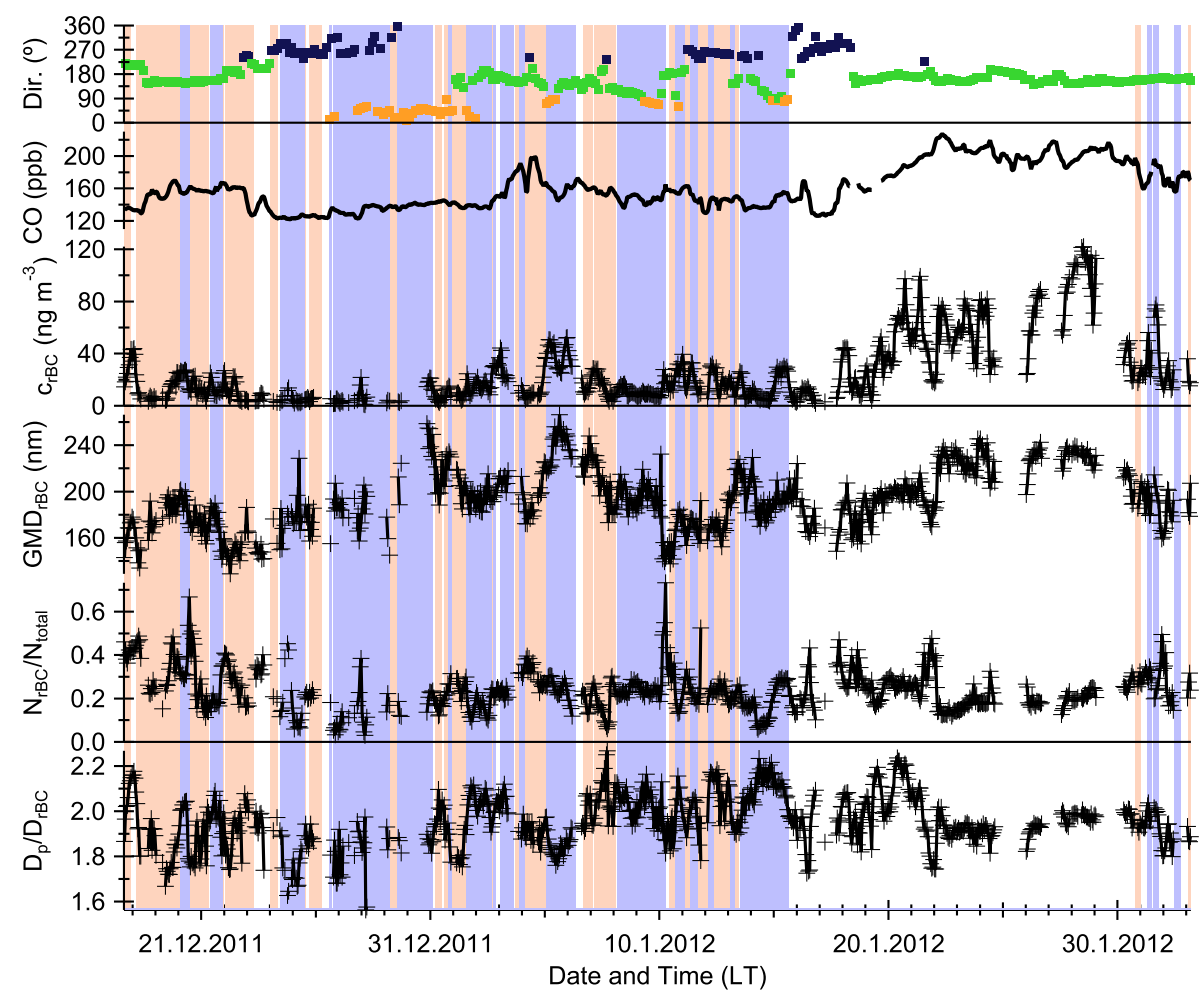

Figure 3. Time series of hourly averages of average trajectory direction (the color is based on three sectors: Arctic Ocean (orange) 0 $90^{\circ}$, continental Europe (green) $90-225^{\circ}$ and North Atlantic (black) 225-360 ${ }^{\circ}$ ), carbon monoxide (CO) concentration, total rBC mass concentration $\left(c_{\mathrm{rBC}}\right)$, geometric mass mean diameter $\left(\mathrm{GMD}_{\mathrm{rBC}}\right)$, the fraction of $350-450 \mathrm{~nm}$ particles containing $\mathrm{rBC}\left(N_{\mathrm{rBC}} / N_{\text {total }}\right)$, and particle to $\mathrm{rBC}$ core diameter ratio for $150-200 \mathrm{~nm} \mathrm{rBC}$ cores $\left(D_{\mathrm{p}} / D_{\mathrm{rBC}}\right)$. Blue background color indicates that the station was in cloud, red means no clouds and white means variable conditions or missing data.

The observed $\mathrm{rBC}$ mass concentration and mean diameter are generally similar to those observed at higher altitudes or from aged air masses (e.g., Huang et al., 2012; Reddington et al., 2013; McMeeking et al., 2010). As these parameters are relatively well known, we focus on the less studied $\mathrm{rBC}$ mixing state (number fraction of $\mathrm{rBC}$ containing particles and particle to $\mathrm{rBC}$ core volume equivalent diameter ratio for these particles). Previous airborne measurements have shown that the diameter ratio $\left(D_{\mathrm{p}} / D_{\mathrm{rBC}}\right)$ is typically close to 1.5 in long-range transported urban and biomass burning plumes (e.g., Kondo et al., 2011; Schwarz et al., 2008a; Sahu et al., 2012; Metcalf et al., 2012), which is significantly smaller than the 2.0 observed at Pallas. Even larger diameter ratios ( 2.4 for $170 \mathrm{~nm} \mathrm{rBC}$ core size) have been observed in an aged (3-4 days) smoke plume, but this is partly caused by the low $\mathrm{rBC}$ core size with mass median diameters ranging from 120 to $160 \mathrm{~nm}$ (Dahlkötter et al., 2014). There is very little published information about the number fraction of particles containing rBC especially in the aged air masses. The closest match with our study is the study of Reddington et al. (2013) who used rBC measurements and model information to estimate that $14 \%$ of particles larger than $260 \mathrm{~nm}$ contain $\mathrm{rBC}$ in the European lower troposphere (altitude less than $2.5 \mathrm{~km}$ above ground level). This fraction is again significantly smaller than the $24 \%$ observed at Pallas. Cloud processing during the long transport from source areas to Pallas is a possible explanation for the high values of particle to $\mathrm{rBC}$ core diameter ratio and $\mathrm{rBC}$ number fraction. Condensation of semi-volatile species to cloud droplets and in-cloud scavenging increase the particle to $\mathrm{rBC}$ core diameter ratio. It is also possible that the $\mathrm{rBC}$ number fraction increases, because wet deposition favors the more hygroscopic $\mathrm{rBC}$-free particles.

In addition to the basic mixing state parameters, careful examination of the scattering and incandescence signals can give additional information about the particle structure. For example, Huang et al. (2012) summarizes number fractions of particles containing both $\mathrm{rBC}$ and non-refractory material (called internally mixed in their paper, but here this term is reserved for particle populations) from several studies (environments) and shows that the number fraction varies between 3 and $80 \%$ (the rest of the rBC containing particles are pure $\mathrm{rBC}$ ). Although different calculation methods can lead to lower values, these numbers are much smaller than that observed at Pallas where practically $100 \%$ of $\mathrm{rBC}$ containing particles are mixed with non-refractory material (pure $\mathrm{rBC}$ 
was not observed). There are also studies where rBC containing particles have disintegrated in the laser beam, which has been interpreted either as a result of very thick non-refractory coatings around rBC cores (Dahlkötter et al., 2014) or that the $\mathrm{rBC}$ is attached to the surface or is close to the surface of a non-absorbing particle (Sedlacek et al., 2012; Moteki et al., 2014), but such behavior was not observed at Pallas.

\subsubsection{Diurnal variations}

Statistically significant diurnal cycles were not observed (not shown), which is not surprising as diurnal variations of solar radiation and temperature are minimal during the Arctic winter. However, when diurnal cycles are calculated separately for the polar night and the following early spring, weak diurnal cycles can be observed in rBC mass concentration, but not in the other aerosol parameters (rBC core diameter and mixing state). During the polar night, rBC mass concentration peaks during midnight, which could indicate regional emissions. After the polar night, $\mathrm{rBC}$ concentration has the maximum during local midday followed by an afternoon decrease, which can be explained by dilution when the mixing layer height increases. In general, other factors such as source region and removal processes during the transport time are more important for the variability of both $\mathrm{rBC}$ mass and mixing state parameters especially during winter.

\subsection{Correlation with other observations}

Most of the rBC parameters have rapid variations (see Fig. 3) compared with the time-scales of variations of the observed trace gas concentrations $\left(\mathrm{CO}, \mathrm{CO}_{2}, \mathrm{NO}_{2}, \mathrm{SO}_{2}\right.$ and $\left.\mathrm{O}_{3}\right)$, meteorological parameters (temperature, pressure, and wind direction and speed) and computed backward trajectories (total length and average direction, distance and altitude). However, at least rBC mass concentration trends can be correlated with certain trace gasses and trajectory (or wind) directions. The other parameters ( $\mathrm{rBC}$ geometric mass mean diameter, number fraction and particle to $\mathrm{rBC}$ core diameter ratio) seem to be less dependent on the meteorological and trajectory parameters and concentrations of the trace gasses.

From the trace gasses, the best correlations are seen between $\mathrm{rBC}$ mass and $\mathrm{CO}, \mathrm{NO}_{2}$ and $\mathrm{CO}_{2}$ concentrations (Pearson's correlation coefficients are between 0.61 and 0.76 ) as these are co-emitted during different combustion processes. Pearson's correlation coefficients for the other rBC parameters (mean diameter and mixing state) and the trace gasses are between -0.35 and 0.42 , which means weak or no correlation. Here we focus on the correlation between rBC mass concentration and carbon monoxide $(\mathrm{CO})$, which is the most commonly used tracer. Concentration time series of $\mathrm{CO}$ is shown in Fig. 3, and Fig. 4 shows the correlation between $\mathrm{rBC}$ and $\mathrm{CO}$ and a linear fit to the data. Pearson's correlation coefficient for the fit is 0.74 , slope $\Delta \mathrm{rBC} / \Delta \mathrm{CO}$ is $0.742 \mathrm{ng} \mathrm{m}^{-3} \mathrm{ppb}^{-1}\left(\mathrm{ppb}=\mathrm{nmol} \mathrm{mol}{ }^{-1}\right)$ and the offset is

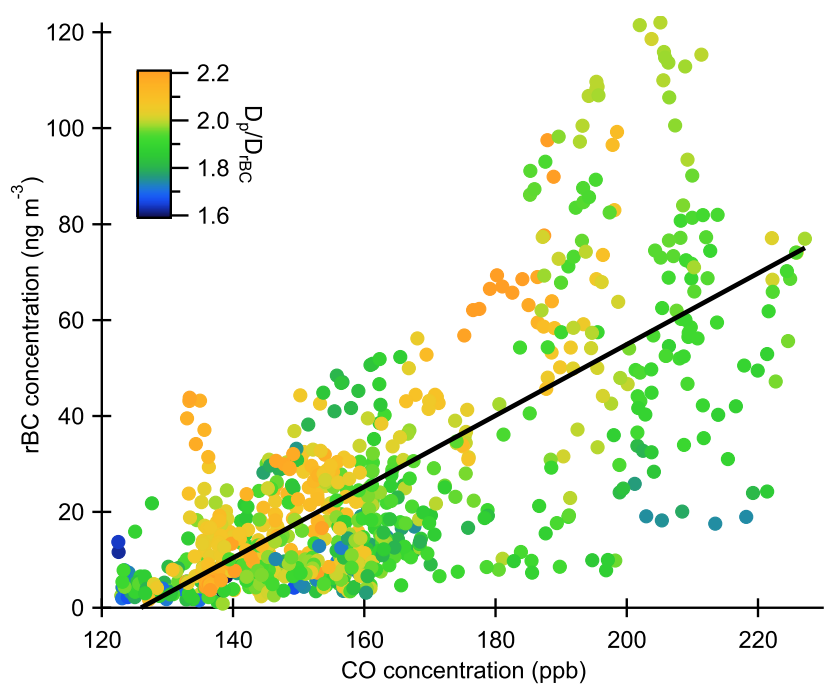

Figure 4. SP2 rBC mass concentration as a function of carbon monoxide (CO) concentration. Marker color shows the particle to rBC core diameter ratio for each data point. The solid black line shows the linear fit to the data.

$-93 \mathrm{ng} \mathrm{m}^{-3}$. Solving the background $\mathrm{CO}$ concentration (CO concentration where $\mathrm{rBC}$ concentration is zero) from the fitted slope and offset gives $126 \mathrm{ppb} . \Delta \mathrm{rBC} / \Delta \mathrm{CO}$ values depend on the aerosol source and the age of the air mass (e.g., McMeeking et al., 2012). Current $\Delta \mathrm{rBC} / \Delta \mathrm{CO}$ value is lower than that from most other SP2 studies focusing on fresh biomass burning, industrial and urban plumes (e.g., Spackman et al., 2008; McMeeking et al., 2010, 2012; Kondo et al., 2011; Baumgardner et al., 2007; Sahu et al., 2012; Taylor et al., 2014). Instead of having different $\mathrm{rBC}$ and $\mathrm{CO}$ sources, the low $\Delta \mathrm{rBC} / \triangle \mathrm{CO}$ value observed at Pallas is more likely the result of aging of the air masses during the transport from source regions to Pallas. The ratio decreases during the transport due to the extended CO lifetime (low levels of solar radiation) and efficient removal of the relatively hydrophilic aged $\mathrm{rBC}$ during the rainy and cloudy winter months. Similar and even lower $\Delta \mathrm{rBC} / \Delta \mathrm{CO}$ values have been observed in free troposphere background air and in air masses that have been experiencing heavy precipitation (Liu et al., 2010; Matsui et al., 2011; Taylor et al., 2014). As can be seen from Fig. 4, the values cover a relatively wide range around the linear fit. This variability does not show clear dependence on the available trajectory, meteorological or $\mathrm{rBC}$ mixing state parameters. As an example, the marker color shows the particle to $\mathrm{rBC}$ core diameter ratio for each data point. Although the higher diameter ratios seem to be mostly above the linear fit, these are not clearly separated from the other data points.

It is assumed that the calculated average trajectory directions (time series shown in Fig. 3) describe the origin of air masses better than the measured local wind directions. Therefore, Fig. 5 shows rBC mass concentration (here $3 \mathrm{~h}$ averages) as a function of average trajectory direction. The tra- 


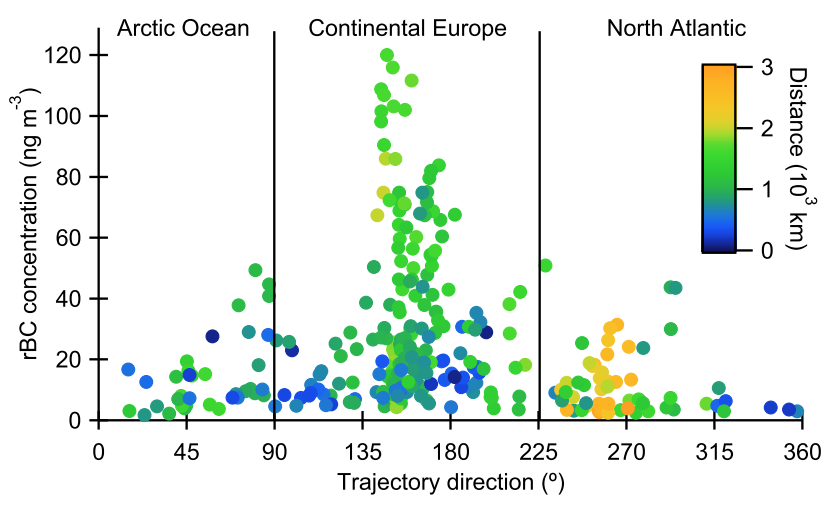

Figure 5. Total $\mathrm{rBC}$ mass concentration as a function of the average trajectory direction. Color scale indicates the average distance of the trajectory coordinate points from Pallas.

jectory directions can be divided into three source regions: Arctic Ocean, continental Europe and North Atlantic. The other trajectory parameters (total length and average altitude and distance) were also examined and it seems that especially the average distance can explain some variations in the observed $\mathrm{rBC}$ concentrations, but these are less dependent on the total length and practically independent of the average altitude. Therefore, each data point in Fig. 5 is colored based on the average distance given as kilometers from the measurement location. In good agreement with the expectations, the figure shows that $\mathrm{rBC}$ concentrations are low when air masses are originating from North Atlantic or Arctic Ocean, and the highest concentrations are observed when trajectories are originating from the southern sector and especially from Eastern Europe (average distance more than $1000 \mathrm{~km}$ ). The lowest concentrations in this polluted sector are observed when air masses are originating mainly from southern Finland and the Baltic Countries (average distance less than $1000 \mathrm{~km}$ ). Again, rBC mixing state and the other size distribution parameters seemed to be independent of air mass origin (total length or average direction, distance or altitude). Especially the fraction of non-refractory material could have been dependent on $\mathrm{rBC}$ source region (age), which was not observed, but it is possible that this data set is too short for finding such dependencies.

It seems that from the $\mathrm{rBC}$ mixing state and size distribution parameters only the $\mathrm{rBC}$ mass concentration is clearly correlated with air mass origin described by trajectories and trace gas concentrations. One reason for the lack of correlations for the other parameters is that these have relatively low variations compared with that of $\mathrm{rBC}$ mass concentration. In addition, the variations seem to have shorter timescales (dayto-day variations) compared with those of the trajectories and trace gas concentrations (Fig. 3).

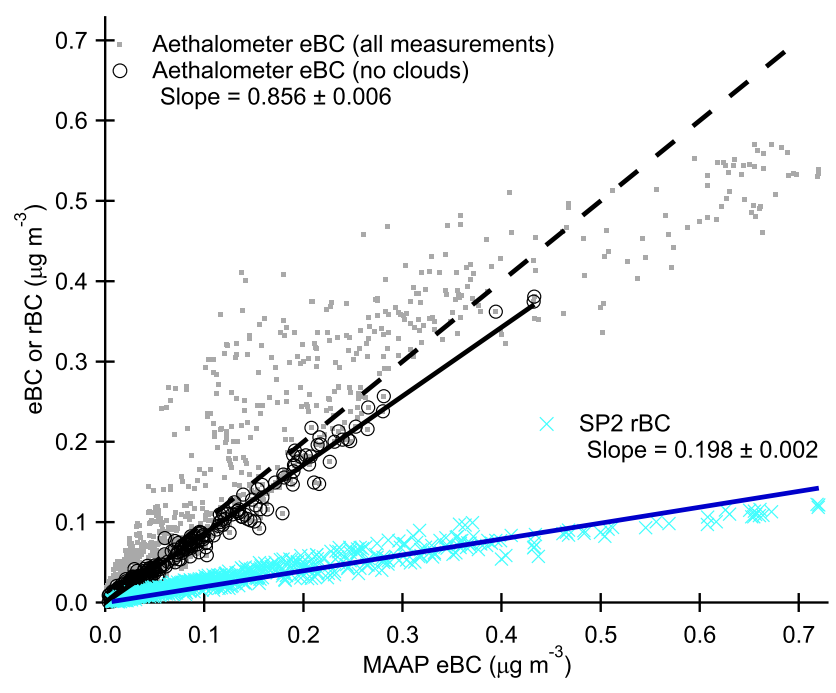

Figure 6. Aethalometer eBC (dots show all measurements and circles are those where the station is not in cloud) and SP2 rBC (crosses) as a function of MAAP eBC as well as linear fits (fixed zero offsets) to the data points. The dashed line shows $1: 1$ slope.

\subsection{Refractory and equivalent black carbon}

MAAP and Aethalometer use optical methods to measure aerosol absorption coefficients which are converted to equivalent $\mathrm{BC}(\mathrm{eBC})$ mass concentrations. Figure 6 shows correlations between these two and $\mathrm{rBC}$ concentration measured by the SP2. The Aethalometer and MAAP eBC concentrations are in good agreement when the Pallas measurement site is not in cloud (circled data points). During the in-cloud conditions and when the presence of clouds is unclear, the $\mathrm{PM}_{10}$ (humid size) eBC measured by MAAP is $30-100 \%$ of the total $\mathrm{eBC}$ measured by the Aethalometer; similar decrease is also expected for the $\mathrm{rBC}$ mass concentration measured by the SP2 during in cloud conditions. $\mathrm{PM}_{10}$ and total eBC concentrations can be similar during the in-cloud conditions if most cloud droplets are smaller than $10 \mu \mathrm{m}$, other than eBC containing particles have been activating or the number fraction of activated particles is low.

The $\mathrm{rBC}$ is about $20 \%$ of the eBC measured by MAAP (both $\mathrm{PM}_{10}$ ), but the fraction is practically constant. This indicates that the difference is not caused by the timedependent aerosol properties such as mixing state. The factor of five difference between eBC and $\mathrm{rBC}$ is significantly larger than could be explained by typical measurement uncertainties (see the Instrumentation section), but there are other potential reasons for the observed difference. First of all, eBC detected by MAAP can contain light absorbing organics generally referred to as brown carbon (e.g. Bond et al., 2013). Since brown carbon is typically non-refractory and weakly absorbing at the near-infrared wavelengths, it cannot be detected by the SP2. However, brown carbon absorption should have a strong wavelength dependency, but this is not seen in 
the Aethalometer data: the average absorption Ångström exponent for wavelengths from 370 to $950 \mathrm{~nm}$ is 1.2 , which is a typical value for black carbon coated with non-absorbing material (Lack and Langridge, 2013). This indicates that brown carbon alone cannot explain the difference between $\mathrm{eBC}$ and $\mathrm{rBC}$. Secondly, SP2 sizing is limited to $75-655 \mathrm{~nm} \mathrm{rBC}$ core volume equivalent diameter range. Although larger $\mathrm{rBC}$ particles, which can be detected but not sized, were rarely observed, $\mathrm{rBC}$ particles smaller than $75 \mathrm{~nm}$ can also have a non-negligible mass. Although the limited sizing range of the SP2 can explain a few time periods with low rBC concentration, it is not likely an explanation for the whole campaign. Third, these instruments have composition-dependent parameters (mass absorption coefficient (MAC) for MAAP and incandescence efficiencies of the calibration and ambient $\mathrm{rBC}$ for SP2), which currently unknown optimal values might differ from the used default values. For example, accumulation of non-refractory material (both internally and externally mixed) to the filter can increase absorption measured by MAAP (Slowik et al., 2007; Cappa et al., 2008), which could be accounted for by increasing MAC. Default MAC $\left(6.6 \mathrm{~m}^{2} \mathrm{~g}^{-1}\right)$ was used in Pallas MAAP data analysis, but larger values up to a factor of two have been reported (e.g., Liu et al., 2010; Bond et al., 2013; Lack et al., 2014). Current SP2 was calibrated using Aquadag ${ }^{\circledR}$, but using a specific batch of fullerene soot which represents ambient aerosol in Tokyo (Moteki and Kondo, 2010) as a calibration material would have given about $33 \%$ larger $\mathrm{rBC}$ mass (Laborde et al., 2012a, b). Using the default MAC for the MAAP and Aquadag ${ }^{\circledR}$ calibration for the SP2 could explain a part of the difference between $\mathrm{eBC}$ and $\mathrm{rBC}$. However, the default MAC and Aquadag ${ }^{\circledR}$ have been used successfully in several studies, so it is unlikely that a bias in these could fully explain the observed factor of five difference. It is therefore possible that a part of the difference is caused by the presence of brown carbon or more generally a light absorbing carbon with high volatility or low absorption at the wavelength used by the SP2.

\subsection{Climate implications}

Several studies have been using numerical models to quantify the effects of black carbon mixing state on aerosol radiative properties and climate (e.g. Bond and Bergstrom, 2006; Adachi et al., 2010; Bond et al., 2013), however, most of these studies are made without detailed experimental information about the mixing state that can be obtained from single particle instruments such as the SP2. In this section we compare the effects of different black carbon mixing state representations on aerosol radiative properties and climate when the models are constrained by our measurements described in the previous sections. From the various mixing state representations (see e.g., Lang-Yona et al., 2010), we have selected two that match with the current observations and three others that are in common use. The five mixing state representations include two internally mixed (only one particle type containing both absorbing and nonabsorbing material) and three externally mixed (separate absorbing and non-absorbing particle types) aerosol populations. The internally mixed particles can be homogenous (INT-HOM) or absorbing cores with a non-absorbing coating (INT-COAT). The externally mixed particles have always one non-absorbing and one absorbing particle type. The absorbing particles can be bare absorbing material (EXTBARE), coated absorbing cores (EXT-COAT) or a homogenous mixture of the absorbing and non-absorbing components (EXT-HOM). Particle structures cannot be directly measured by the SP2, but single particle imaging studies have shown that aged ambient particles are typically composed of a compact black carbon cluster mixed with non-absorbing material, which is often described by a homogenous particle or a coated black carbon core model (e.g. Bond et al., 2013). If it is assumed that the black carbon forms a distinct core then the EXT-COAT case is the one closest to our observations, but otherwise EXT-HOM case is more appropriate.

All model calculations are based on the same total particle size distribution and chemical composition (campaign averages), but the absorbing and non-absorbing species are distributed differently in each mixing state representation. Based on our measurements, the average total rBC mass concentration is $26 \mathrm{ng} \mathrm{m}^{-3}$, the number fraction of particles containing $\mathrm{rBC}$ is 0.24 and particle to $\mathrm{rBC}$ core diameter ratio is 2.0. This means that the total $\mathrm{rBC}$ volume fraction is $0.24 / 2.0^{3}=0.03$ and the rest is non-refractory material. Also, the total volume of all particles must be $460 \times 10^{-9} \mathrm{~cm}^{3} \mathrm{~m}^{-3}$ based on the observed $\mathrm{rBC}$ mass concentration (density is $1800 \mathrm{~kg} \mathrm{~m}^{-3}$ ) and volume fraction (0.03). Because SP2 does not detect scattering particles smaller than $190 \mathrm{~nm}$, particle size distribution parameters are obtained from the gas line DMPS measurements: geometric volume mean diameter and standard deviation are $323 \mathrm{~nm}$ and 1.54 , respectively. Volume distribution is used here, because particles larger than $100 \mathrm{~nm}$ have the dominant effect on light absorption and scattering. As described in Sect. 3.4, refractory black carbon (rBC) detected by the SP2 is only about $20 \%$ of the equivalent black carbon (eBC) measured by the MAAP. Here we assume that the difference is caused by the presence of non-refractory light absorbing organic carbon (LAC) which cannot be detected by the SP2. Based on the average $\mathrm{rBC}$ to eBC ratio of 0.21 , $\mathrm{eBC}$ volume fraction is 0.15 and the $\mathrm{LAC}$ volume fraction is $0.12(\mathrm{eBC}=\mathrm{rBC}+\mathrm{LAC})$. The rest of the total volume is assumed to be ammonium sulfate. Optical constants of the different particle types are calculated as a volume fraction weighted average of those of the pure compounds. The complex refractive indices of ammonium sulfate, LAC and $\mathrm{rBC}$ are $1.51+0 i, 1.95+0.79 i$ (Baumgardner et al., 2007) and $2.26+1.26 i$ (Moteki et al., 2010), respectively. Simple illustration of the five different mixing state representations is shown in Fig. 7. In the EXT-COAT case, $24 \%$ of the particles 

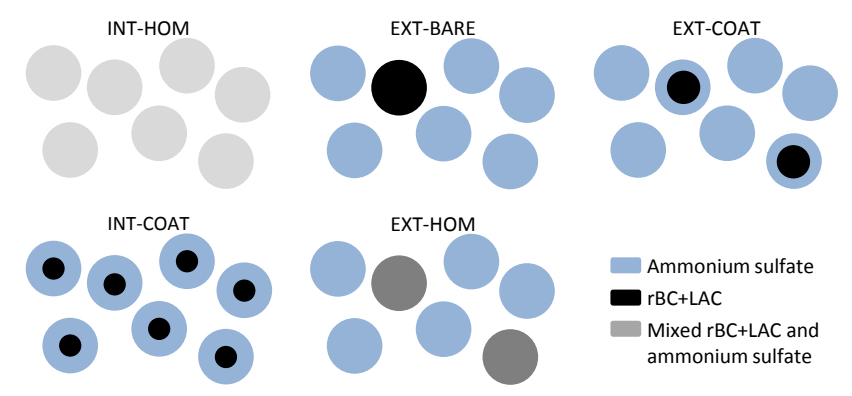

Figure 7. Illustration of the particle compositions for the five mixing state representations.

are absorbing and the remaining $76 \%$ are composed of nonabsorbing ammonium sulfate. The absorbing particles contain a core, which is composed of a mixture of $\mathrm{rBC}\left(1 / 2.0^{3}\right.$ of the particle volume $)$ and LAC $\left(0.12 / 0.03 \times 1 / 2.0^{3}\right.$ of the particle volume), and the coating is ammonium sulfate. The EXT-HOM case is similar to that except that the absorbing particles are homogeneous mixtures of the three components. The EXT-BARE case has the same total amount of absorbing material, which means that the absorbing particle number fraction is the same as the total absorbing volume fraction. The INT-HOM and INT-COAT cases are constructed so that the absorbing volume fraction in each particle is the same as the total absorbing volume fraction.

Numerical calculations using the Bohren and Huffman (1983) BHMIE and BHCOAT codes give extinction $\left(b_{\text {ext }}\right)$ and absorption coefficients $\left(b_{\text {abs }}\right)$ and backscatter fraction $(b)$ for the particle populations at $550 \mathrm{~nm}$ wavelength. These are the main parameters in an equation for global mean top of atmosphere radiative forcing efficiency (RFE) per unit optical depth (Haywood and Shine, 1995; Anderson et al., 1999):

$\mathrm{RFE}=S D\left(1-A_{\mathrm{c}}\right) T_{\mathrm{a}}^{2}\left(1-R_{\mathrm{S}}\right)^{2}\left(\frac{2 R_{\mathrm{S}}(1-\omega)}{\left(1-R_{\mathrm{S}}\right)^{2}}-\beta \omega\right)$.

The parameters are solar constant $\left(S=1370 \mathrm{~W} \mathrm{~m}^{-2}\right)$, annual average daylight fraction $(D=0.5)$, fractional cloud coverage $\left(A_{\mathrm{c}}=0.6\right)$, atmospheric transmissivity $\left(T_{\mathrm{a}}=0.87\right)$, surface albedo $\left(R_{\mathrm{S}}=0.2\right)$, single scattering albedo $(\omega=1-$ $b_{\text {abs }} / b_{\text {ext }}$ ), and average upscatter fraction $(\beta)$. The upscatter fraction is parameterized as a function of backscatter fraction $b: \beta=0.082+1.85 b-2.97 b^{2}$ (Anderson et al., 1999). Although Eq. (1) is a highly simplified solution for a complex problem and its parameters have uncertainties, which means that the absolute RFE values are not fully accurate; this equation is suitable for comparing different mixing state models.

The results of the calculations, which include extinction and absorption coefficients and backscatter fraction used in Eq. (1), are given in Table 1. Because the absorbing material is distributed over all particles in the internally mixed aerosol, which means larger effective absorption cross section, this aerosol is more absorbing and less scattering than the externally mixed aerosol where only a fraction of par-
Table 1. Extinction $\left(b_{\text {ext }}\right)$ and absorption $\left(b_{\text {abs }}\right)$ coefficients and backscatter fraction $(b)$ for the five mixing state representations. Radiative forcing efficiency (RFE) is calculated using Eq. (1).

\begin{tabular}{lrrrr}
\hline & $\begin{array}{r}b_{\text {ext }} \\
\left(\mathrm{Mm}^{-1}\right)\end{array}$ & $\begin{array}{r}b_{\text {abs }} \\
\left(\mathrm{Mm}^{-1}\right)\end{array}$ & $b$ & $\begin{array}{r}\text { RFE } \\
\left(\mathrm{W} \mathrm{m}^{-2}\right)\end{array}$ \\
\hline INT-HOM & 3.98 & 1.58 & 0.09 & 11.20 \\
INT-COAT & 3.63 & 1.53 & 0.16 & 9.11 \\
EXT-BARE & 3.43 & 0.56 & 0.11 & -10.93 \\
EXT-HOM & 3.58 & 0.79 & 0.11 & -5.46 \\
EXT-COAT & 3.51 & 0.75 & 0.11 & -6.54 \\
\hline
\end{tabular}

ticles are absorbing (e.g., Cappa et al., 2012). Mainly due to the differences in single scattering albedo, RFE values are positive (warming effect) for the internally mixed aerosol and negative (cooling effect) for the externally mixed aerosol. As the current and most other experimental results show that at least the aged $\mathrm{rBC}$ aerosol population is externally mixed, assuming an internally mixed aerosol would lead to an overestimated climate warming effect. Compared with the overall difference in RFE between the internally and externally mixed absorbing aerosol populations, the effect of single particle structure on RFE is small. This means that at least in this case the number fraction of absorbing particles is more important for the aerosol radiative forcing than the exact single particle structure.

\section{Conclusions}

We have measured refractory black carbon (rBC) mass distributions and mixing state by using a Single Particle Soot Photometer (SP2) at an Arctic measurement site in northern Finland. To our knowledge, these are the first published surface SP2 measurements made in the Fennoscandian Arctic. The results show that $\mathrm{rBC}$ mass concentrations are relatively low (average mass concentration $26 \mathrm{ng} \mathrm{m}^{-3}$ ) and most of the $\mathrm{rBC}$ is long-range transported from the south. Observed $\mathrm{rBC}$ core sizes (geometric mass mean diameter $194 \mathrm{~nm}$ ) are typical for aged air masses. On average, $24 \%$ of the accumulation mode particles contain an observable (volume equivalent diameter at least $75 \mathrm{~nm}$ ) rBC core. These particles contain large fractions of non-refractory material with the average particle to $\mathrm{rBC}$ core diameter ratio 2.0; bare $\mathrm{rBC}$ particles or other than mixed particle structures (e.g. rBC attached to non-absorbing particles) were not observed.

From the rBC mass distribution and mixing state parameters only the mass concentration was clearly correlated with certain co-emitted trace gasses. The correlation of $\mathrm{rBC}$ with carbon monoxide (CO) showed shallow slope, which was interpreted as a result of relatively aged air masses where $\mathrm{rBC}$ has been removed mainly by wet deposition. Similarly, rBC mass concentration was also the only parameter that correlated with air mass history described by the average direc- 
tions and lengths of backward trajectories. The largest concentrations were observed when the trajectories were originating from Eastern Europe and the lowest concentrations were from North Atlantic and Arctic Ocean.

SP2 measurements provided detailed information about the $\mathrm{rBC}$ mixing state, but the observations are not always in agreement with the mixing state representations used in various aerosol models. The effects of absorbing aerosol mixing state on aerosol radiative properties were estimated by using a Mie approximation and a simple direct radiative forcing efficiency calculations. The difference between single particle structures (e.g. absorbing core coated with non-absorbing material or homogenous absorbing particle) is small compared with that between internally (all particles are absorbing) and externally (a fraction of particles are absorbing) mixed absorbing aerosol populations. The internally mixed aerosol population is more absorbing due to the higher effective absorbing cross sectional area, which means that these aerosols are more likely to have a warming effect. However, the same aerosol can have a cooling effect when assuming externally mixed absorbing and non-absorbing particles. Our current and most other observations show that especially the aged aerosol is externally mixed, which means that assuming an internally mixed homogenous aerosol means overestimated aerosol warming effect.

Current radiative forcing calculations are highly simplified, so more detailed model calculations should be done to obtain a more realistic radiative forcing estimate. Before that can be done, accurate measurements are needed to develop a global picture of the mixing state of the absorbing aerosol. Long-term measurements are also needed to observe the diurnal and annual cycles. SP2 is probably the best instrument for that purpose, but this requires consistent use of data analysis methods and reference materials.

Acknowledgements. This work was supported by the EU LIFE+ project MACEB (project no. LIFE09 ENV/FI/000572), the Academy of Finland project Greenhouse gas, aerosol and albedo variations in the changing Arctic (project number 269095), the Academy of Finland through the FCoE in Physics, Chemistry, Biology and Meteorology of Atmospheric Composition and Climate Change (program numbers 1118615 and 272041), black and brown carbon influence on climate and climate change in India - from local to regional scale (project no. 264242), Arctic Absorbing Aerosols and Albedo of Snow (project no. 3162), the Nordic research and innovation initiative CRAICC, and KONE foundation. We would also like to thank J. Hatakka and T. Laurila for providing the gas data.

Edited by: A. Laskin

\section{References}

Adachi, K., Chung, S. H., and Buseck, P. R.: Shapes of soot aerosol particles and implications for their effects on climate, J. Geophys. Res., 115, D15206, doi:10.1029/2009JD012868, 2010.

Anderson, T. L., Covert, D. S., Wheeler, J. D., Harris, J. M., Perry, K. D., Trost, B. E., Jaffe, D. J., and Ogren, J. A.: Aerosol backscatter fraction and single scattering albedo: Measured values and uncertainties at a coastal station in the Pacific Northwest, J. Geophys. Res., 104, 26793-26807, 1999.

Baumgardner, D., Kok, G., and Raga, G.: Warming of the Arctic lower stratosphere by light absorbing particles, Geophys. Res. Lett., 31, L06117, doi:10.1029/2003GL018883, 106117, 2004.

Baumgardner, D., Kok, G. L., and Raga, G. B.: On the diurnal variability of particle properties related to light absorbing carbon in Mexico City, Atmos. Chem. Phys., 7, 2517-2526, doi:10.5194/acp-7-2517-2007, 2007.

Baumgardner, D., Popovicheva, O., Allan, J., Bernardoni, V., Cao, J., Cavalli, F., Cozic, J., Diapouli, E., Eleftheriadis, K., Genberg, P. J., Gonzalez, C., Gysel, M., John, A., Kirchstetter, T. W., Kuhlbusch, T. A. J., Laborde, M., Lack, D., Müller, T., Niessner, R., Petzold, A., Piazzalunga, A., Putaud, J. P., Schwarz, J., Sheridan, P., Subramanian, R., Swietlicki, E., Valli, G., Vecchi, R., and Viana, M.: Soot reference materials for instrument calibration and intercomparisons: a workshop summary with recommendations, Atmos. Meas. Tech., 5, 1869-1887, doi:10.5194/amt-51869-2012, 2012.

Bohren, C. and Huffman, D. R.: Absorption and scattering of light by small particles, Wiley, New York, 1983.

Bond, T. C. and Bergstrom, R. W.: Light Absorption by Carbonaceous Particles: An Investigative Review, Aerosol Sci. Tech., 40, 27-67, doi:10.1080/02786820500421521, 2006.

Bond, T. C., Doherty, S. J., Fahey, D. W., Forster, P. M., Berntsen, T., DeAngelo, B. J., Flanner, M. G., Ghan, S., Kärcher, B., Koch, D., Kinne, S., Kondo, Y., Quinn, P. K., Sarofim, M. C., Schultz, M. G., Schulz, M., Venkataraman, C., Zhang, H., Zhang, S., Bellouin, N., Guttikunda, S. K., Hopke, P. K., Jacobson, M. Z., Kaiser, J. W., Klimont, Z., Lohmann, U., Schwarz, J. P., Shindell, D., Storelvmo, T., Warren, S. G., and Zender, C. S.: Bounding the role of black carbon in the climate system: A scientific assessment, J. Geophys. Res., 118, 5380-5552, doi:10.1002/jgrd.50171, 2013.

Cappa, C. D., Lack, D. A., Burkholder, J. B., and Ravishankara, A. R.: Bias in Filter-Based Aerosol Light Absorption Measurements Due to Organic Aerosol Loading: Evidence from Laboratory Measurements, Aerosol Sci. Tech., 42, 1022-1032, doi:10.1080/02786820802389285, 2008.

Cappa, C. D., Onasch, T. B., Massoli, P., Worsnop, D. R., Bates, T. S., Cross, E. S., Davidovits, P., Hakala, J., Hayden, K. L., Jobson, B. T., Kolesar, K. R., Lack, D. A., Lerner, B. M., Li, S.-M., Mellon, D., Nuaaman, I., Olfert, J. S., Petäjä, T., Quinn, P. K., Song, C., Subramanian, R., Williams, E. J., and Zaveri, R. A.: Radiative Absorption Enhancements Due to the Mixing State of Atmospheric Black Carbon, Science, 337, 1078-1081, doi:10.1126/science.1223447, 2012.

Dahlkötter, F., Gysel, M., Sauer, D., Minikin, A., Baumann, R., Seifert, P., Ansmann, A., Fromm, M., Voigt, C., and Weinzierl, B.: The Pagami Creek smoke plume after long-range transport to the upper troposphere over Europe - aerosol properties and 
black carbon mixing state, Atmos. Chem. Phys., 14, 6111-6137, doi:10.5194/acp-14-6111-2014, 2014.

Draxler, R.: HYSPLIT4 user's guide, NOAA Tech. Memo. ERL ARL-230, NOAA Air Resources Laboratory, Silver Spring, MD, 1999.

Draxler, R. and Hess, G.: Description of the HYSPLIT_4 modeling system., NOAA Tech. Memo. ERL ARL-224, NOAA Air Resources Laboratory, Silver Spring, MD, 24 pp., 1997.

Draxler, R. and Hess, G.: An overview of the HYSPLIT_4 modeling system of trajectories, dispersion, and deposition, Aust. Meteorol. Mag., 47, 295-308, 1998.

Dutkiewicz, V. A., DeJulio, A. M., Ahmed, T., Laing, J., Hopke, P. K., Skeie, R. B., Viisanen, Y., Paatero, J., and Husain, L.: Forty-seven years of weekly atmospheric black carbon measurements in the Finnish Arctic: Decrease in black carbon with declining emissions, J. Geophys. Res., 119, 7667-7683, doi:10.1002/2014JD021790, 2014.

Flanner, M. G., Zender, C. S., Randerson, J. T., and Rasch, P. J.: Present-day climate forcing and response from black carbon in snow, J. Geophys. Res., 112, D11202, doi:10.1029/2006JD008003, 2007.

Gao, R. S., Schwarz, J. P., Kelly, K. K., Fahey, D. W., Watts, L. A., Thompson, T. L., Spackman, J. R., Slowik, J. G., Cross, E. S., Han, J.-H., Davidovits, P., Onasch, T. B., and Worsnop, D. R.: A Novel Method for Estimating LightScattering Properties of Soot Aerosols Using a Modified SingleParticle Soot Photometer, Aerosol Sci. Tech., 41, 125-135, doi:10.1080/02786820601118398, 2007.

Genberg, J., Denier van der Gon, H. A. C., Simpson, D., Swietlicki, E., Areskoug, H., Beddows, D., Ceburnis, D., Fiebig, M., Hansson, H. C., Harrison, R. M., Jennings, S. G., Saarikoski, S., Spindler, G., Visschedijk, A. J. H., Wiedensohler, A., Yttri, K. E., and Bergström, R.: Light-absorbing carbon in Europe - measurement and modelling, with a focus on residential wood combustion emissions, Atmos. Chem. Phys., 13, 87198738, doi:10.5194/acp-13-8719-2013, 2013.

Gysel, M., Laborde, M., Olfert, J. S., Subramanian, R., and Gröhn, A. J.: Effective density of Aquadag and fullerene soot black carbon reference materials used for SP2 calibration, Atmos. Meas. Tech., 4, 2851-2858, doi:10.5194/amt-4-2851-2011, 2011.

Hansen, A., Rosen, H., and Novakov, T.: The aethalometer An instrument for the real-time measurement of optical absorption by aerosol particles, Sci. Total Environ., 36, 191-196, doi:10.1016/0048-9697(84)90265-1, 1984.

Hansen, J. and Nazarenko, L.: Soot climate forcing via snow and ice albedos, P. Natl. Acad. Sci. USA, 101, 423-428, doi:10.1073/pnas.2237157100, 2004.

Hatakka, J., Aalto, T., Aaltonen, V., Aurela, M., Hakola, H., Komppula, M., Laurila, T., Lihavainen, H., Paatero, J., Salminen, K., and Viisanen, Y.: Overview of the atmospheric research activities and results at Pallas GAW station, Boreal Environ. Res., 8, 365-383, 2003.

Haywood, J. M. and Shine, K. P.: The effect of anthropogenic sulfate and soot aerosol on the clear sky planetary radiation budget, Geophys. Res. Lett., 22, 603-606, doi:10.1029/95GL00075, 1995.

Huang, X.-F., Sun, T.-L., Zeng, L.-W., Yu, G.-H., and Luan, S.-J.: Black carbon aerosol characterization in a coastal city in South
China using a single particle soot photometer, Atmos. Environ., 51, 21-28, 2012.

Hyvärinen, A.-P., Kolmonen, P., Kerminen, V.-M., Virkkula, A., Leskinen, A., Komppula, M., Hatakka, J., Burkhart, J., Stohl, A., Aalto, P., Kulmala, M., Lehtinen, K., Viisanen, Y., and Lihavainen, H.: Aerosol black carbon at five background measurement sites over Finland, a gateway to the Arctic, Atmos. Environ., 45, 4042-4050, 2011.

IPCC: Climate Change 2013: The Physical Science Basis. Contribution of Working Group I to the Fifth Assessment Report of the Intergovernmental Panel on Climate Change, edited by: Stocker, T. F., Qin, D., Plattner, G.-K., Tignor, M., Allen, S. K., Boschung, J., Nauels, A., Xia, Y., Bex, V., and Midgley, P., Cambridge University Press, Cambridge, United Kingdom and New York, NY, USA, 1535 pp., 2013.

Kipling, Z., Stier, P., Schwarz, J. P., Perring, A. E., Spackman, J. R., Mann, G. W., Johnson, C. E., and Telford, P. J.: Constraints on aerosol processes in climate models from vertically-resolved aircraft observations of black carbon, Atmos. Chem. Phys., 13, 5969-5986, doi:10.5194/acp-13-5969-2013, 2013.

Komppula, M., Lihavainen, H., Kerminen, V.-M., Kulmala, M., and Viisanen, Y.: Measurements of cloud droplet activation of aerosol particles at a clean subarctic background site, J. Geophys. Res., 110, D06204, doi:10.1029/2004JD005200, 2005.

Kondo, Y., Matsui, H., Moteki, N., Sahu, L., Takegawa, N., Kajino, M., Zhao, Y., Cubison, M. J., Jimenez, J. L., Vay, S., Diskin, G. S., Anderson, B., Wisthaler, A., Mikoviny, T., Fuelberg, H. E., Blake, D. R., Huey, G., Weinheimer, A. J., Knapp, D. J., and Brune, W. H.: Emissions of black carbon, organic, and inorganic aerosols from biomass burning in North America and Asia in 2008, J. Geophys. Res., 116, D08204, doi:10.1029/2010JD015152, 2011.

Laborde, M., Mertes, P., Zieger, P., Dommen, J., Baltensperger, U., and Gysel, M.: Sensitivity of the Single Particle Soot Photometer to different black carbon types, Atmos. Meas. Tech., 5, 10311043, doi:10.5194/amt-5-1031-2012, 2012a.

Laborde, M., Schnaiter, M., Linke, C., Saathoff, H., Naumann, K.H., Möhler, O., Berlenz, S., Wagner, U., Taylor, J. W., Liu, D., Flynn, M., Allan, J. D., Coe, H., Heimerl, K., Dahlkötter, F., Weinzierl, B., Wollny, A. G., Zanatta, M., Cozic, J., Laj, P., Hitzenberger, R., Schwarz, J. P., and Gysel, M.: Single Particle Soot Photometer intercomparison at the AIDA chamber, Atmos. Meas. Tech., 5, 3077-3097, doi:10.5194/amt-5-3077-2012, 2012b.

Lack, D. A. and Langridge, J. M.: On the attribution of black and brown carbon light absorption using the Ångström exponent, Atmos. Chem. Phys., 13, 10535-10543, doi:10.5194/acp13-10535-2013, 2013.

Lack, D., Moosmüller, H., McMeeking, G., Chakrabarty, R., and Baumgardner, D.: Characterizing elemental, equivalent black, and refractory black carbon aerosol particles: a review of techniques, their limitations and uncertainties, Anal. Bioanal. Chem., 406, 99-122, doi:10.1007/s00216-013-7402-3, 2014.

Lang-Yona, N., Abo-Riziq, A., Erlick, C., Segre, E., Trainic, M., and Rudich, Y.: Interaction of internally mixed aerosols with light, Phys. Chem. Chem. Phys., 12, 21-31, doi:10.1039/B913176K, 2010. 
Lihavainen, H., Hyvärinen, A., Asmi, E., Hatakka, J., and Viisanen, Y.: Long-term variability of aerosol optical properties in northern Finland, Boreal Environ. Res., 20, 526-541, 2015.

Liu, D., Flynn, M., Gysel, M., Targino, A., Crawford, I., Bower, K., Choularton, T., Jurányi, Z., Steinbacher, M., Hüglin, C., Curtius, J., Kampus, M., Petzold, A., Weingartner, E., Baltensperger, U., and Coe, H.: Single particle characterization of black carbon aerosols at a tropospheric alpine site in Switzerland, Atmos. Chem. Phys., 10, 7389-7407, doi:10.5194/acp-10-73892010, 2010.

Liu, D., Allan, J., Whitehead, J., Young, D., Flynn, M., Coe, H., McFiggans, G., Fleming, Z. L., and Bandy, B.: Ambient black carbon particle hygroscopic properties controlled by mixing state and composition, Atmos. Chem. Phys., 13, 2015-2029, doi:10.5194/acp-13-2015-2013, 2013.

Matsui, H., Kondo, Y., Moteki, N., Takegawa, N., Sahu, L. K., Zhao, Y., Fuelberg, H. E., Sessions, W. R., Diskin, G., Blake, D. R., Wisthaler, A., and Koike, M.: Seasonal variation of the transport of black carbon aerosol from the Asian continent to the Arctic during the ARCTAS aircraft campaign, J. Geophys. Res., 116, D05202, doi:10.1029/2010JD015067, 2011.

McMeeking, G. R., Hamburger, T., Liu, D., Flynn, M., Morgan, W. T., Northway, M., Highwood, E. J., Krejci, R., Allan, J. D., Minikin, A., and Coe, H.: Black carbon measurements in the boundary layer over western and northern Europe, Atmos. Chem. Phys., 10, 9393-9414, doi:10.5194/acp-10-9393-2010, 2010.

McMeeking, G. R., Bart, M., Chazette, P., Haywood, J. M., Hopkins, J. R., McQuaid, J. B., Morgan, W. T., Raut, J.-C., Ryder, C. L., Savage, N., Turnbull, K., and Coe, H.: Airborne measurements of trace gases and aerosols over the London metropolitan region, Atmos. Chem. Phys., 12, 5163-5187, doi:10.5194/acp12-5163-2012, 2012.

Metcalf, A. R., Craven, J. S., Ensberg, J. J., Brioude, J., Angevine, W., Sorooshian, A., Duong, H. T., Jonsson, H. H., Flagan, R. C., and Seinfeld, J. H.: Black carbon aerosol over the Los Angeles Basin during CalNex, J. Geophys. Res., 117, D00V13, doi:10.1029/2011JD017255, 2012.

Moteki, N. and Kondo, Y.: Dependence of Laser-Induced Incandescence on Physical Properties of Black Carbon Aerosols: Measurements and Theoretical Interpretation, Aerosol Sci. Tech., 44, 663-675, doi:10.1080/02786826.2010.484450, 2010.

Moteki, N., Kondo, Y., Miyazaki, Y., Takegawa, N., Komazaki, Y., Kurata, G., Shirai, T., Blake, D. R., Miyakawa, T., and Koike, M.: Evolution of mixing state of black carbon particles: Aircraft measurements over the western Pacific in March 2004, Geophys. Res. Lett., 34, L11803, doi:10.1029/2006GL028943, 2007.

Moteki, N., Kondo, Y., and Nakamura, S.: Method to measure refractive indices of small nonspherical particles: Application to black carbon particles, J. Aerosol Sci., 41, 513-521, 2010.

Moteki, N., Kondo, Y., and Adachi, K.: Identification by singleparticle soot photometer of black carbon particles attached to other particles: Laboratory experiments and ground observations in Tokyo, J. Geophys. Res., 119, 1031-1043, doi:10.1002/2013JD020655, 2014.

Petzold, A. and Schönlinner, M.: Multi-angle absorption photometry - a new method for the measurement of aerosol light absorption and atmospheric black carbon, J. Aerosol Sci., 35, 421-441, doi:10.1016/j.jaerosci.2003.09.005, 2004.
Petzold, A., Ogren, J. A., Fiebig, M., Laj, P., Li, S.-M., Baltensperger, U., Holzer-Popp, T., Kinne, S., Pappalardo, G., Sugimoto, N., Wehrli, C., Wiedensohler, A., and Zhang, X.-Y.: Recommendations for reporting "black carbon" measurements, Atmos. Chem. Phys., 13, 8365-8379, doi:10.5194/acp-13-83652013, 2013.

Reddington, C. L., McMeeking, G., Mann, G. W., Coe, H., Frontoso, M. G., Liu, D., Flynn, M., Spracklen, D. V., and Carslaw, K. S.: The mass and number size distributions of black carbon aerosol over Europe, Atmos. Chem. Phys., 13, 4917-4939, doi:10.5194/acp-13-4917-2013, 2013.

Sahu, L. K., Kondo, Y., Moteki, N., Takegawa, N., Zhao, Y., Cubison, M. J., Jimenez, J. L., Vay, S., Diskin, G. S., Wisthaler, A., Mikoviny, T., Huey, L. G., Weinheimer, A. J., and Knapp, D. J.: Emission characteristics of black carbon in anthropogenic and biomass burning plumes over California during ARCTAS-CARB 2008, J. Geophys. Res., 117, D16302, doi:10.1029/2011JD017401, 2012.

Samset, B. H., Myhre, G., Herber, A., Kondo, Y., Li, S.-M., Moteki, N., Koike, M., Oshima, N., Schwarz, J. P., Balkanski, Y., Bauer, S. E., Bellouin, N., Berntsen, T. K., Bian, H., Chin, M., Diehl, T., Easter, R. C., Ghan, S. J., Iversen, T., Kirkevåg, A., Lamarque, J.-F., Lin, G., Liu, X., Penner, J. E., Schulz, M., Seland, Ø., Skeie, R. B., Stier, P., Takemura, T., Tsigaridis, K., and Zhang, K.: Modelled black carbon radiative forcing and atmospheric lifetime in AeroCom Phase II constrained by aircraft observations, Atmos. Chem. Phys., 14, 12465-12477, doi:10.5194/acp14-12465-2014, 2014.

Schwarz, J. P., Gao, R. S., Fahey, D. W., Thomson, D. S., Watts, L. A., Wilson, J. C., Reeves, J. M., Darbeheshti, M., Baumgardner, D. G., Kok, G. L., Chung, S. H., Schulz, M., Hendricks, J., Lauer, A., Kärcher, B., Slowik, J. G., Rosenlof, K. H., Thompson, T. L., Langford, A. O., Loewenstein, M., and Aikin, K. C.: Single-particle measurements of midlatitude black carbon and light-scattering aerosols from the boundary layer to the lower stratosphere, J. Geophys. Res., 111, D16207, doi:10.1029/2006JD007076, 2006.

Schwarz, J. P., Gao, R. S., Spackman, J. R., Watts, L. A., Thomson, D. S., Fahey, D. W., Ryerson, T. B., Peischl, J., Holloway, J. S., Trainer, M., Frost, G. J., Baynard, T., Lack, D. A., de Gouw, J. A., Warneke, C., and Del Negro, L. A.: Measurement of the mixing state, mass, and optical size of individual black carbon particles in urban and biomass burning emissions, Geophys. Res. Lett., 35, L13810, doi:10.1029/2008GL033968, 2008a.

Schwarz, J. P., Spackman, J. R., Fahey, D. W., Gao, R. S., Lohmann, U., Stier, P., Watts, L. A., Thomson, D. S., Lack, D. A., Pfister, L., Mahoney, M. J., Baumgardner, D., Wilson, J. C., and Reeves, J. M.: Coatings and their enhancement of black carbon light absorption in the tropical atmosphere, J. Geophys. Res., 113, D03203, doi:10.1029/2007JD009042, 2008 b.

Schwarz, J. P., Samset, B. H., Perring, A. E., Spackman, J. R., Gao, R. S., Stier, P., Schulz, M., Moore, F. L., Ray, E. A., and Fahey, D. W.: Global-scale seasonally resolved black carbon vertical profiles over the Pacific, Geophys. Res. Lett., 40, 5542-5547, doi:10.1002/2013GL057775, 2013.

Sedlacek, A. J., Lewis, E. R., Kleinman, L., Xu, J., and Zhang, Q.: Determination of and evidence for non-core-shell structure of particles containing black carbon using the Single-Particle 
Soot Photometer (SP2), Geophys. Res. Lett., 39, L06802, doi:10.1029/2012GL050905, 2012.

Slowik, J. G., Cross, E. S., Han, J.-H., Davidovits, P., Onasch, T. B., Jayne, J. T., Williams, L. R., Canagaratna, M. R., Worsnop, D. R., Chakrabarty, R. K., Moosmüller, H., Arnott, W. P., Schwarz, J. P., Gao, R.-S., Fahey, D. W., Kok, G. L., and Petzold, A.: An Inter-Comparison of Instruments Measuring Black Carbon Content of Soot Particles, Aerosol Sci. Tech., 41, 295-314, doi:10.1080/02786820701197078, 2007.

Stephens, M., Turner, N., and Sandberg, J.: Particle identification by laser-induced incandescence in a solid-state laser cavity, Appl. Optics, 42, 3726-3736, doi:10.1364/AO.42.003726, 2003.

Stohl, A., Klimont, Z., Eckhardt, S., Kupiainen, K., Shevchenko, V. P., Kopeikin, V. M., and Novigatsky, A. N.: Black carbon in the Arctic: the underestimated role of gas flaring and residential combustion emissions, Atmos. Chem. Phys., 13, 8833-8855, doi:10.5194/acp-13-8833-2013, 2013.

Spackman, J. R., Schwarz, J. P., Gao, R. S., Watts, L. A., Thomson, D. S., Fahey, D. W., Holloway, J. S., de Gouw, J. A., Trainer, M., and Ryerson, T. B.: Empirical correlations between black carbon aerosol and carbon monoxide in the lower and middle troposphere, Geophys. Res. Lett., 35, L19816, doi:10.1029/2008GL035237, 2008.

Svensson, J., Virkkula, A., Meinander, O., Kivekäs, N., Hannula, H.-R., Järvinen, O., Peltoniemi, J. I., Gritsevich, M., Heikkilä, A., Kontu, A., Hyvärinen, A.-P., Neitola, K., Brus, D., Dagsson-Waldhauserova, P., Anttila, K., Hakala, T., Kaartinen, H., Vehkamäki, M., de Leeuw, G., and Lihavainen, H.: Soot on snow experiments: light-absorbing impurities effect on the natural snowpack, The Cryosphere Discuss., 9, 1227-1267, doi:10.5194/tcd-9-1227-2015, 2015.

Taylor, J. W., Allan, J. D., Allen, G., Coe, H., Williams, P. I., Flynn, M. J., Le Breton, M., Muller, J. B. A., Percival, C. J., Oram, D., Forster, G., Lee, J. D., Rickard, A. R., Parrington, M., and Palmer, P. I.: Size-dependent wet removal of black carbon in Canadian biomass burning plumes, Atmos. Chem. Phys., 14, 13755-13771, doi:10.5194/acp-14-13755-2014, 2014.
Taylor, J. W., Allan, J. D., Liu, D., Flynn, M., Weber, R., Zhang, X., Lefer, B. L., Grossberg, N., Flynn, J., and Coe, H.: Assessment of the sensitivity of core/shell parameters derived using the single-particle soot photometer to density and refractive index, Atmos. Meas. Tech., 8, 1701-1718, doi:10.5194/amt-81701-2015, 2015.

Wang, Q., Jacob, D. J., Spackman, J. R., Perring, A. E., Schwarz, J. P., Moteki, N., Marais, E. A., Ge, C., Wang, J., and Barrett, S. R. H.: Global budget and radiative forcing of black carbon aerosol: Constraints from pole-to-pole (HIPPO) observations across the Pacific, J. Geophys. Res., 119, 195-206, doi:10.1002/2013JD020824, 2014.

Wang, X., Heald, C. L., Ridley, D. A., Schwarz, J. P., Spackman, J. R., Perring, A. E., Coe, H., Liu, D., and Clarke, A. D.: Exploiting simultaneous observational constraints on mass and absorption to estimate the global direct radiative forcing of black carbon and brown carbon, Atmos. Chem. Phys., 14, 10989-11010, doi:10.5194/acp-14-10989-2014, 2014.

Weingartner, E., Saathoff, H., Schnaiter, M., Streit, N., Bitnar, B., and Baltensperger, U.: Absorption of light by soot particles: determination of the absorption coefficient by means of aethalometers, J. Aerosol Sci., 34, 1445-1463, 2003.

Zhang, R., Khalizov, A. F., Pagels, J., Zhang, D., Xue, H., and McMurry, P. H.: Variability in morphology, hygroscopicity, and optical properties of soot aerosols during atmospheric processing, P. Natl. Acad. Sci. USA, 105, 10291-10296, doi:10.1073/pnas.0804860105, 2008. 